\title{
FIRST LANGUAGE INFLUENCE ON SECOND LANGUAGE WRITING AND EXPRESSION
}

Peter Mtuze

The case study has its source in the author's attempt to translate his novelette Alitshoni lingaphumi (Waiting for sunrise) into English. Current developments in the sociopolitical arena make it increasingly important for linguists to focus on the interchange between the indigenous languages and the two dominant languages, English and Afrikaans. This would break down the artificial baniers so enthusiastically maintained in the past. Secondly, such an exercise would also help to overcome prejudicial ignorance. Some of the issues highlighted include culturastructural, lexicsyntactic, and semantic differences between Xhosa and English, as exemplified in the text in question.

Die vertrekpunt vir die gevallestudie is die skrywer se poging om sy novelle Alitshoni lingaphumi (Wagtend op sonsopkoms) in Engels te vertaal. In die lig van eietydse ontwikkelinge in die sosio-politiese arena, word dit vir linguiste toenemend belangrik om te fokus op die wisselwerking tussen die inheemse tale en die twee dominante tale, Engels en Afrikaans. Dit sou die kunsmatige skeiding wat in die verlede met soveel entoesiasme gehandhaaf is, ajbreek Dit sou ook die onkunde wat uit vooroordeel spruit, oorkom, Van die sake wat na aanleiding van die teks na vore gebring word, sluit die kulturele, strukturele, leksikale, sintaktiese en semantiese verskille tussen Xhosa en Engels in.

\section{$1 \quad$ INTRODUCTION}

There is general agreement that one's first language (Ll) has a decided influence on one's second language (12) writing and expression. In South Africa many studies have been conducted on the influence of Afrikaans, for example, on the kind of English spoken by some Afrikaans mother-tongue speakers, and vice versa. Little, to my knowledge, has been written on the influence of the various $\mathrm{i} \cdot$ enous languages on the two major official languages as spoken by black South Africans. general tendency is to denigrate their English as deficient English, typical of non-mother- tongue speakers without understanding the powerful effect of a mother-tongue. Our linguistic situation in South Africa is analogous with that in USA and Australia, but Black American English, Australian English and many other English variants are considered worthy of study and are not sti matised. Of course, this change of attitude came about only more recently, after lingmsts like Labov challenged the notion of linguistic deficit. A sensitivity towards black English is all the more imperative in the light of current deve where more and more black children are entering formerly whites-on schools.

The idea for this topic arose when I translated one of my latest Xhosa books into English. The first draft of the manuscript had to be submitted to an English editor who made several corrections to my black South African English.

In order to appreciate fully the influence of my mother-tongue on the kind of English I write and speak, it will be necessary for the reader to have some insight into my background in the English language. I began studying English in Substandard B at school. That was some forty three years ago. I subsequently studied through the medium of English up to Matric and then at three different non-ethnic universities, finally obtaining a doctoral degree. In addition, I have worked as an interpreter for more than twenty-five years in all and hold a B A (Translation) degree from Rhodes University, specialising in English and Afrikaans translation. Despite all this bombardment of English, the translation exercise mentioned above shows how tenaciously my mother-tongue affects me. 


\section{LANGUAGE VARIATIONS HIGHLIGHTED AND EXPLORED}

Literary translation is by its very nature a very taxing exercise. Although I shall be touching on some translation problems in this text, I shall enerally avoid technicalities in my discussion. The main thrust of the study will be L1 mfluence on L2. One of the main obstacles in such translation is one's cultural background as Wylie (1991:39) points out when he writes 'the problematics of translation pragmatic adequacy in the cross-cultural transfer o onnation may be achieved, any language will inevitably withhold a margin of uniquely resonant cultural concepts and connotations which resist expression in a foreign tongue'.

I wrote the book in question, Alitshoni lingaphumi, in Xhosa in 1986. It was one of the sixteen creative works published by that time, and I can, therefore, claim some measure of maturity and success as far as my mother-tongue is concerned - a claim which I can hardly repeat as far as English is concerned, even allowing for some degree of modesty.

To contextualise the analyses, a brief synopsis of the novelette must be iven. The novelette focuses on the plight of farm labourers in the Middelburg Cape dtstrict. This community is hit by a series of economic, social and political tragedies. The first is abuse and deprivation at the hands of unsympathetic white farmers. The second is a devastating drought that leads to massive unemployment as farmers are forced to cut down on human power. The workers and thetr families end up on the outskirts of Middelburg Cape where they stay in appalling conditions until they are allowed into the neighbouring township from which the Urban Areas Act had strictly forbidden them in the past. Their position is aggravated when they are later removed by force to Msobomvu in Ciskei where worse conditions await them. They are caught in the rising political tide which is spearheaded by their own children who want to replace them with more militant and more energetic community leaders. When the dust settles, they all come together and a spirit of conciliation emerges in Msobomvu.

In translating the book, I tried to keep within two important parameters, fidelity and naturalness, as espoused by Mary Bill (1982:93) which she explains with regard to English translation of Tsonga texts as follows: 'By fidelity I mean faithfulness to the original message. By naturalness, I mean the reproduction in English of the original message. so that the English reader will perceive it with the nuances of meaning, and with something of the emotional impact which the message conveys to the reader' (author has substituted SL for Tsonga).

\section{$2.1 \quad$ THE TITLE}

My first problem was how to render the title appropriately in English. After agonising for some time, I decided to go for the literal, noncontroversial rendition: The sun never sets forever.

Though the title sounded correct to someone whose mother-tongue is Xhosa, it was problematic in English as the Xhosa version was culture bound. The same connotations could not be expressed in English without elaboration. Never and the present tense form sets did not appear to be correct when used with forever. The other option, The sun does not set for_ever seemed too plain and pedantic. It was only after having translated the whole book that I eventually came up with the current title Waiting for sunrise which seems to be both creative and more in line with the source language idiom.

\subsection{PRESENT CONTINUOUS TENSE AND THE SIMPLE PAST TENSE}

The present continuous tense is very popular in Xhosa in cases where English prefers the s1mple past tense. To highlight the problems experienced with tense, I shall refer to my original attempt as UV (unedited version) and to the edited version as EV. 
JV: Nkomiyahlaba is moving up and down.

V: Nkomiyahlaba moved up and down.

1lis problem manifested itself throughout the first draft even when I opted for the past ense form was it would still be accompanied by the present continuous form:

JV: He was openly telling everyone that he was more interested in his livestock thain loafers.

$\mathrm{V}$ : He told everyone openly that he was more interested in his livestock than in loafers.

\subsection{AFRIKAANS INFLUENCE}

n one or two cases, Afrikaans influence manifested itself:

JV: He should give way from my farm instead of He must leave my farm.

lhe editor simply queried the original as being from Afrikaans (gee pad) and did not Lctually suggest the correct English version, hence my not indicating it as the edited •ersion.

\subsection{THE USE OF CLICHES AND FIGURATIVE EXPRESSIONS}

\{hosa differs from English in that the use of idioms, figurative expressions and so-called :liches is regarded as a sign of elegance and good command of the language in Xhosa. $\mathrm{n}$ English these are not as highly regarded. Several of these expressions had to be :liminated from the English version. In some cases, these had to be paraphrased in the ranslation, eg. Amadoda akafani afana ngeentshebe kuphela. This was rendered as 'No wo men are alike even though their beards could look the same.' At one stage the nemories of that great poem 'The charge of the light brigade' influenced me to express me thought in a cliche: 'theirs was not to reason why but to do and die' which the editor vas not enthusiastic about. Of course, some of the expressions used such as 'one of those hings' were colloquialisms, for instance :

JV: Between those rather polarised characters, there were numerous others which the farm workers either knew or to which they were accustomed. They had come to accept them as one of those things.

V: Between those polarised characters, there were numerous others which the farm workers either knew or to whom they were accustomed. They had come to accept them asjacts_of_life.

ven when I tried to paraphrase Xhosa expressions, they remained foreign to the English anguage speaker. One of the statements made in the book is Ndokha ndibone ukuba ozala nkomoni na. This was rendered loosely as 'I shall see what this will come to' vhich clearly does not make sense. The first reason for its not makinsense is that the tatement seems to be a straight-forward statement whereas in Xhosa 1t carries the idea If 'eagerly awaiting the outcome'.

\section{$2.5 \quad$ UNTRANSLATABLE WORDS AND EXPRESSIONS}

Some words are either untranslatable or very difficult to convey in the other language, :g. the common South African term 'Baas' which reflects a unique master-servant elationship. To translate this as 'Boss' is not correct at all because the term loses its pecifically black-white flavour. Even gangsters have bosses. I had to use the words 
'Baas' and 'Klein Baas' as neologisms from Afrikaans. I could not use 'master' as one cannot translate 'Klein Baas' as 'Young master'. Of course, this also helps to retain the master and servant milieu that forms the basis of the novelette.

Names also fall into this category. Black people are very fond of giving white people suitable and very descriptive nicknames. When translated, these names lose their nch connotations. One such example is Maqhajana which I translated as Mr Lategan thereby forfeiting the attributes of boldness and audacity associated with the Xhosa name. Mrs Lategan was also known as Nongqwaza which means someone eccentric. The same problem was experienced with Mphephuka, the sinewy farm boy who was nicknamed Domkrag (Afrikaans for a jack) which the editor wanted chan ed to Jack. Jack, in this sense, seems to lose the connotation of strength since it ts a common name not associated with the equipment.

\subsection{DISTINCTIONS NOT MADE IN XHOSA}

Part of the second languae problem emanates from the fact that certain words have a dual meaning in Xhosa while in English one needs to use a different word with a cognate meaning. 'Live' is always confused with 'stay' by second language speakers such as myself, even after all these years. The reason for this is that Xhosa has only one word hlala which either means 'live' or 'stay'. Another such word is boleka which either means

'borrow' or 'lend'. Xhosa mother-tongue speakers would use the two words interchangeably because the distinction is not made in Xhosa. Of course, there is no chance of misunderstanding since the concord caters for the distinction between Ndibaleke imali 'I borrowed money from someone' and Ndakukubaleka imali 'I shall lend you money.'

\subsection{QUANTIFIERS}

Sometimes the editor could not make sense of my English, for instance, when I wrote 'Some were streaminin large numbers from the huts.' It seems there is a problem when one uses same in conJunction with large numbers. The Xhosa word amanye (some) does not create any problem as it could be used to refer to either a small number or to a large number.

\section{$2.8 \quad$ NO EQUIVALENT NOUN IN ENGLISH}

One of the problems occurred when I tried to translate the Xhosa noun iphatha, which has no equivalent in English. The word refers to one who is ambidextrous. Of course, one can paraphrase this by using an adjective: 'the ambidextrous Ndokwenza'.

\subsection{IDIOMATIC DIFFERENCES}

Sometimes the errors were as a result of my not being completely at home with the English idiom, eg.

UV: Everyone burst out in laughter

EV: Everyone burst out laughing.

Once again, the Xhosa statement wonke umntu wathi gquzu ngentsini which has a subject, predicate and a non-verbal extension could be responsible for the error. 
Second language speakers are prone to mixing tenses. It is not uncommon to find them L!Sing the past tense in conjunction with the present tense, eg. 'He saw that he is going to drown' instead of 'He saw that he was going to drown.' The second language speaker annat see the logic in using the past tense in the case of drowning in this context as the vent of drowning itself is still impending or likely and has not materialised. That is why Xhosa uses the future tense in this regard Wabona_ukuba_uza_kurlzaxwa. This tallies with oing but differs from was_going. To the second language speaker, therefore, the following reported statement in EV is ambiguous:

UV: He ended up his short address with that joke and everyone burst in laughter, others pulling Phangalele's leg by saying he is a well known drunkard

EV: He ended his short address with that joke and everyone burst out laughing, others pulling Phangalele's leg by saying he was a well known drunkard.

\subsection{KINSHIP TERMS AND OTHER SOCIAL REFERENCES}

Another problem area in this exercise is kinship terms and other social references since these are also culture-bound. Throughout the manuscript, reference is made to sisi, huti and tata. Sisi in Xhosa does not only mean one's elder sister. It can also refer to a woman or girl as old as one's elder sister. These extensions of meaning also apply to huti (one's elder brother) and tata (one's father). Depending on the context, the terms, in each case, can mean any one of the three while the English equivalents refer only to one's sister, brother and father, respectively.

Another classic example in this regard is that in Xhosa the children of brothers are also brothers and sisters (as the case may be) whereas in the English kinship system they are cousins. Add to this the broad clan system, and a man then has not only several fathers but also several hundreds of brothers and sisters.

In an earlier article entitled 'Problems of equivalence and adequacy in a trilingual context', I commented on translation problems which arise:

There are certain cultural issues that are very difficult to put across in the other lan uage, worse still if that language is a 'non-African langua e' such as English and Afnkaans. That is why, in many cases, earlier language practitiOners especially in the legal profession - wisely decided to borrow terms directly from the vernacular, for example:

ukutlzwala instead of 'abduction', ukungena custom instead of something like 'inheriting a deceased person's wife', lobola instead of 'bride-price' or 'dowry'. (Mtuze 1990:30)

\subsection{LANGUAGE OF AVOIDANCE}

Another peculiarity as far as Xhosa social life is concerned is with regard to hloniplza or the language of avoidance. Xhosa women in traditional society do not call - their husbands or senior in-laws by their names. That is why the main character's wife, Nongcucalazo, calls her husband Ta'kaSpantou which means Spantou's father. Because this phenomenon is unknown in Western society, I had to make do with the clumsy lookmg 'Father-of-Spantou'. Of course, trying to retain the texture of the original is not a bad thing as pointed out by Wylie (1990:41) who aptly states that "at the end of the continuum, a writer may retam sufficient sense of the cultural self to wrest the adopted language back towards home". 


\subsection{3}

USE OF WRONG REGISTER

Choosing the correct word in each case is not always easy for the second language speaker as shown by the following example:

UV: He first asked for the erection of a school on the farm because he was worried about children who did not attend school.

EV: He first asked for the building of a school on the farm because he was worried about children who did not attend school.

Once again, Xhosa does not make such a distinction. ukwakha refers to both erect and build. Of course, even in English, the difference is very subtle, a matter of formality.

\subsection{CONCEPTUAL DIFFERENCES}

Finally, I observed that a second language speaker always conceptualises issues through his or her mother-tongue conceptual framework as illustrated by the following sentence:

UV: The people's plight started very slowly and gently.

EV: The people's plight deteriorated very gradually and almost imperceptibly.

Here there is a subtle difference of conceptual focus. The one kind of plight starts slowly and gently while the other is an existent situation the worsens gradually.

\section{CONCLUSION}

One could go on ad nauseum pinpointing various differences between the L1 and the $\boldsymbol{U}$ speakers of English. Suffice it to say this is a field of study which deserves further attention. It is a field that can offer rewarding insights to linguists and communicators at all levels in their quest to minimise misunderstandings. If English is to be the lingua franca as suggested in some circles, then these finer points of difference in how we speak the language should be carefully monitored.

\section{REFERENCES}

Bill, Mary C. 1982. The blanket of darkness: Problems in translatinfrom a Bantu language into English. The South African Journal for Afncan Languages, 2(3): 91-117.

Mtuze, PT 1990. Problems of equivalence and adequacy in a trilingual context. The South African Journal for African Languages, 8(1\}:30-32.

Wylie, D. 1991. Language thieves: English-language strategies in two Zimbabwean novellas. English in Africa, 18(2\}: 40-62. 